\title{
Parasite load in intact and ulcerative skin of dogs with leishmaniais
}

\author{
Carga parasitária em fragmentos de pele intacta e ulcerada em cães com leishmaniose \\ Francine Maria de França Silva ${ }^{1}$; Edna Michely de Sá Santos ${ }^{1}$; Sandra Maria Torres ${ }^{1}$; Elise Miyuki Yamasak ${ }^{1}$; \\ Rafael Antonio Nascimento Ramos²; Leucio Câmara Alves ${ }^{1}$
}

\begin{abstract}
${ }^{1}$ Departamento de Medicina Veterinária, Universidade Federal Rural de Pernambuco - UFRPE, Recife, PE, Brasil
${ }^{2}$ Unidade Acadêmica de Garanhuns, Universidade Federal Rural de Pernambuco - UFRPE, Garanhuns, PE, Brasil
\end{abstract}

Received June 9, 2015

Accepted July 22, 2015

\begin{abstract}
The skin is the site of inoculation of Leishmania spp. in susceptible hosts, and consequently dermatopathies, especially ulcerative dermatitis, are the main clinical signs observed. The aim of this study was to assess parasitism of the skin (intact and ulcerated) among dogs that were naturally infected by Leishmania spp., through immunohistochemical analysis. Skin fragments (intact and ulcerated) were collected from 13 dogs with positive parasitological (bone marrow aspiration and exfoliative skin) and serological examinations (ELISA S7 ${ }^{\circ}$ Biogene) for Leishmania spp. These samples were processed using the immunohistochemical technique, involving the streptavidin-peroxidase complex. Ulcerative lesions were mainly observed on the elbows $(53.84 \% ; 7 / 13)$, nostrils $(15.38 \% ; 2 / 13)$, ears $(23.07 \% ; 3 / 13)$ and wings of the ilium $(7.69 \% ; 1 / 13)$. A severe parasite load was detected in $46.15 \%$ and $76.92 \%$ of the intact and ulcerated skin samples tested, respectively. The parasite load on ulcerated skin was statistically higher than on intact skin $(\mathrm{p}=0.0221)$. These results indicate that the intact and ulcerated skin may host a high parasite load of amastigote forms of Leishmania spp., which can favor the transmission of the parasite.
\end{abstract}

Keywords: Skin, leishmaniasis, immunohistochemistry, reservoir, dog.

\section{Resumo}

A pele é o local de inoculação da Leishmania spp. nos hospedeiros susceptíveis e dessa forma, as dermatopatias, principalmente as dermatites ulcerativas são os principais sinais clínicos observados. O objetivo deste estudo foi avaliar o parasitismo na pele (íntegra e ulcerada) em cáes naturalmente infectados por Leishmania spp. através da técnica de imunohistoquímica. Fragmentos de pele (íntegra e ulcerada) foram coletados de 13 cães com diagnóstico parasitológico (aspirado de medula óssea e esfoliação cutânea) e sorológico positivos (ELISA S7 ${ }^{\circledR}$ Biogene) para Leishmania spp. Amostras foram processadas por imunohistoquímica pelo complexo estreptoavidina-peroxidase. As lesóes ulcerativas foram observadas principalmente nas regióes do cotovelo $53,84 \%$ (7/13), narina $15,38 \%(2 / 13)$, orelha $23,07 \%(3 / 13)$ e sobre a asa do ílio 7,69\% (1/13). Uma intensa carga parasitária foi detectada 46,15\% e 76,92\% das amostras de pele íntegra e ulcerada, respectivamente. A carga parasitária na pele ulcerada foi estatisticamente superior à pele íntegra $(\mathrm{p}=0,0221)$. Esses resultados indicam que a pele intacta e ulcerada pode albergar uma intensa carga parasitária de formas amastigotas de Leishmania spp., o que pode favorecer a transmissão do parasita.

Palavras-chave: Pele, leishmaniose, imunohistoquímica, reservatório, cão.

Visceral leishmaniasis (VL) is an important disease caused by Leishmania infantum parasites that may affect several species of animals, including dogs (GRAMICCIA, 2011). Positive dogs may present $\mathrm{VL}$ in forms ranging from asymptomatic infection to severe disease, which may present systemic involvement and have a wide variety of clinical signs, such as lymphadenopathy, weight

*Corresponding author: Rafael Antonio Nascimento Ramos. Unidade Acadêmica de Garanhuns, Universidade Federal Rural de Pernambuco UFRPE, Avenida Bom Pastor, s/n, Boa Vista, CEP 55292-270, Garanhuns, PE, Brasil. e-mail: rafaelanramos10@yahoo.com.br loss, ocular lesions, circulatory disorders, chronic kidney disease and dermatopathies (CHAMIZO et al., 2005).

The main cutaneous alterations in canine visceral leishmaniasis (CVL) include alopecia, onychogryphosis, desquamation, ulcerative lesions, hyperkeratosis, hypotrichosis and presence of localized or generalized crusts (REIS et al., 2006; QUEIROZ et al., 2010). In CVL, the dermatological patterns presented by dogs are characterized by desquamative and ulcerative patterns, along with pustular and nodular lesions (FERRER et al., 1988). These ulcerative lesions may be observed on the nostrils, lips, face, periocular region, ears and areas of bone projections, especially in the humerus-radioulnar 
region, calcaneus and ischial tuberosity (CAMINHA \& SOTOBLANCO, 2008; TORRES-NETO et al., 2008).

In this context, the skin represent an excellent biological sample for detection of amastigote forms in parasitological tests (e.g. exfoliative cytology), immunostaining (TAFURI et al., 2004; QUEIROZ et al., 2011) or parasite DNA detection (QUEIROZ et al., 2011; REIS et al., 2013, RAMOS et al., 2013). Indeed, assessment of the parasite load in both healthy and ulcerated skin fragments from dogs could contribute towards better understanding of their role as parasite reservoirs for $L$. infantum transmission to susceptible hosts (SOLANO-GALLEGO et al., 2004). Therefore, the aim of this study was to assess the parasite load in the intact and ulcerated skin of dogs positive for Leishmania spp..

This study was conducted using 13 positive dogs for Leishmnania spp. of different ages, breeds and sex. The animals were being kept at the Zoonotic Disease Control Centers of the municipalities of Petrolina (9 $23^{\prime} 39^{\prime \prime} \mathrm{S}, 40^{\circ} 30^{\prime} 35^{\prime \prime} \mathrm{W}$ ) and Goiana (7³4' 19" S, $35^{\circ} 0$ ' $\left.7^{\prime \prime}\right)$, both located in the state of Pernambuco, Brazil. All procedures performed in this study were approved by the Ethics Committee for Animal Use (ECAU) of the Federal Rural University of Pernambuco (protocol number 010/2011).

All the animals were clinically examined and the dermatological alterations presented were classified as previously proposed (FERRER et al., 1988). All dogs were diagnosed positive at enzyme-linked immunosorbent assay (ELISA S7 ${ }^{\circ}$ Biogene) and microscopic cytological examination of exfoliative skin tissue and bone marrow biopsy material. Intact skin fragments were collected from the scapular region, while ulcerated skin was obtained from any part of the body at the periphery of the skin lesion. All the fragments were collected using a biopsy punch $(4 \mathrm{~mm})$ and were then fixed in 10\% buffered formalin for 48 hours. Following this, they were transferred to glass vials containing a solution of $70 \%$ ethanol until the time of immunohistochemical processing.

For the immunohistochemical examination, immunolabeling of the amastigote forms of Leishmania spp. was performed using the streptavidin-peroxidase technique (TAFURI et al., 2004). Skin from a dog with intense cutaneous parasitism due to Leishmania spp. was used as a positive control. In addition, skin from a negative dog confirmed by PCR examination of bone marrow and skin was used as negative control.

The intensity of parasitism was reported as the number of immunolabeled amastigote forms and was expressed as the mean number observed in five microscope fields at 400X magnification. The parasite load was defined as follows: $(-)$ absent, $(+)$ low, $(++)$ moderate and $(+++)$ high, corresponding to $0,1-100,101-300$ and > 300 amastigote forms of Leishmania spp., respectively (GIUNCHETTI et al., 2006).

Differences among the parasite loads in the skin fragments were statistically analyzed through the Mann-Whitney test using the Biostat 5.0 software (AYRES et al., 2007). Differences were considered statistically significant when $\mathrm{P} \leq 0.05$.

All the animals examined here presented at least one cutaneous clinical sign. These dermatological alterations ranged from ulcerative lesions to scaly alopecia. Ulcerative lesions were mainly observed on the elbows $(53.84 \% ; 7 / 13)$, nostrils $(15.38 \% ; 2 / 13)$, ears $(23.07 \% ; 3 / 13)$ and wings of the ilium $(7.69 \% ; 1 / 13)$.
Severe parasitism was observed in $46.15 \%(6 / 13)$ of the intact skin samples and in $76.92 \%(10 / 13)$ of the ulcerated skin samples (Figure 1). The overall results regarding the parasite load are reported in Table 1 . Interestingly, the parasite load detected in ulcerated skin samples was higher than that recorded for intact skin samples $(\mathrm{p}=0.0238)$.

In this study, the cutaneous parasitism of 13 dogs that were naturally infected by Leishmania spp. was assessed. The presence of skin lesions observed here is a common clinical finding in CVL cases and may occur in $45 \%$ of the infected dogs (GIUNCHETTI et al., 2006; COSTA et al., 2008). In the animals studied, the ulcerative lesions were observed mainly on the elbows. It is known that the presence of ulcerative dermatitis is normally associated with areas of bone projections (FERRER et al., 1988).

All the skin fragments (both the intact and the ulcerated skin samples) analyzed here through immunohistochemical examination scored positive. In fact, the immunohistochemical technique enables high contrast between amastigote forms of Leishmania spp. and the host tissue, thus enabling a more accurate diagnosis (ORDEIX et al., 2005; TAFURI et al., 2004; FIGUEIREDO et al., 2010). The parasite load in ulcerated samples was statistically higher than that in intact skin samples. These results differ from

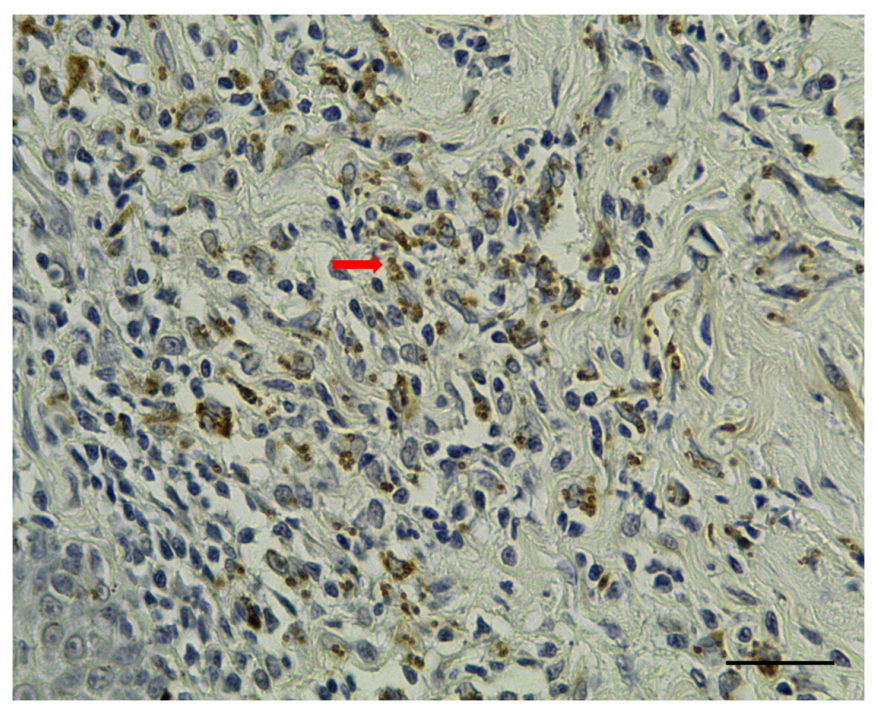

Figure 1. Photomicrograph of the skin of a dog that was naturally infected by Leishmania spp.. Lesioned dermis with an ulcerative dermatological pattern in a dog with a severe parasite load (immunohistochemical evaluation by means of the streptavidin-peroxidase technique); Note the presence of numerous intracytoplasmic amastigotes of Leishmania spp. in the macrophage revealed by immunohistochemistry (red arrow) (scale bar $=50 \mu \mathrm{m})$.

Table 1. Semi-quantitative assessment of parasite load by means of immunohistochemistry on the intact and ulcerated skin samples from dogs that were naturally infected by Leishmania spp.

\begin{tabular}{lccr}
\hline \multirow{2}{*}{ Skin } & \multicolumn{3}{c}{ Parasite load } \\
\cline { 2 - 4 } & \multicolumn{1}{c}{ Mild } & \multicolumn{1}{c}{ Moderate } & \multicolumn{1}{c}{ Severe } \\
\hline Intact & $4 / 13(30.76 \%)$ & $3 / 13(23.07 \%)$ & $6 / 13(46.15 \%)$ \\
Ulcerated & $2 / 13(15.38 \%)$ & $1 / 13(7.69 \%)$ & $10 / 13(76.92 \%)$ \\
\hline
\end{tabular}


those reported by Papadogiannakis et al. (2005), who did not detect any significant difference between the parasitism in the two skin samples.

Our findings suggest that the mild parasitic load on intact skin samples $(30.76 \%)$ reported here most likely occurred due to an early immune response with participation by macrophages and by IL-4, TNF- $\alpha$ and IFN- $\gamma$, which play an important role in parasite control (CALABRESE et al., 2010; MENEZES-SOUZA et al., 2012; VERAS et al., 2010). It is important to highlight that $46.15 \%(6 / 13)$ of the intact skin samples exhibited a severe parasite load. Failure of the local cellular immune response probably did not allow efficient parasite control (CALABRESE et al., 2010; MENEZES-SOUZA et al., 2012). In addition, this high parasite load may have been associated with the chronic phase of the disease (REIS et al., 2006).

The presence of moderate and severe parasite loads in intact skin samples suggests that, even without macroscopic lesions, the infected animal can exhibit a large number of parasites, thereby playing an important role as a source of infection for phlebotomine vectors (TAFURI et al., 2004; LAURENTI et al., 2013). In intact skin fragments, a higher number of amastigote forms may be detected around the hair follicle and the dermal vascular plexus, thus suggesting that spreading of Leishmania spp. may occur via blood (SOLANO-GALLEGO et al., 2004).

Predominantly intense parasite load, rather than moderate and mild parasitism, has previously been reported as a difference between symptomatic and asymptomatic dogs (GIUNCHETTI et al., 2006). By contrast, Saridomichelakis et al. (2007) did not find any association between parasite load and the severity of skin lesions.

The present study demonstrates that intact and ulcerated skin may host a high number of amastigote forms of Leishmania spp., which can favor transmission of the parasite. Over the last years, the role of asymptomatic dogs in the life cycle of leishmaniasis has been extensively disputed. Recently, a study suggested that both symptomatic and asymptomatic animals are potentially infective to sand flies (LAURENTI et al., 2013). In addition, it has been demonstrated that only the cutaneous parasitism is not pivotal for successful transmissibility (TRAVI et al., 2001). Therefore, animals where cutaneous lesions are absent, may act as important source of infection by phlebotomine sand flies.

\section{References}

Ayres M, Ayres Jr M, Ayres DL, Santos AS. BioEstat 5.0: aplicaçōes estatísticas nas áreas das ciências bio-médicas. Belém: Sociedade Civil Mamirauá; 2007.

Calabrese KS, Cortada VM, Dorval ME, Souza Lima MA, Oshiro ET, Souza CS, et al. Leishmania (Leishmania) infantum/chagasi: histopathological aspects of the skin in naturally infected dogs in two endemic areas. Exp Parasitol 2010; 124(3): 253-257. http://dx.doi.org/10.1016/j. exppara.2009.10.005. PMid:19854175.

Caminha AEQ, Soto-Blanco B. Clinical features of canine visceral leishmaniasis at Fortaleza city, Ceará, Brazil. Arch Vet Sci 2008; 13(3): 218-222.

Chamizo C, Moreno J, Alvar J. Semi-quantitative analysis of cytokine expression in asymptomatic canine leishmaniasis. Vet Immunol Immunopathol
2005; 103(1-2): 67-75. http://dx.doi.org/10.1016/j.vetimm.2004.08.010. PMid:15626462.

Costa MMS, Lima WG, Figueiredo MM, Michalick MSM, Tafuri WL, Tafuri WL. Cervical, mandibular, and parotid lymph nodes of dogs naturally infected with Leishmania infantum: a histopathologic and immunohistochemistry study and its correlation with facial skin lesions. Vet Pathol 2008; 45(5): 613-616. http://dx.doi.org/10.1354/ vp.45-5-613. PMid:18725463.

Ferrer L, Rabanal R, Fondevila D, Ramos JA, Domingo M. Skin lesions in canine leishmaniasis. J Small Anim Pract 1988; 29(6): 381-388. http:// dx.doi.org/10.1111/j.1748-5827.1988.tb02298.x.

Figueiredo MM, Moura EP, Costa MM, Ribeiro VM, Michalick MS, Tafuri WL, et al. Histopathological and parasitological investigations of ear healthy skin of dogs naturally and experimentally infected with Leishmania (Leishmania) chagasi. Histol Histopathol 2010; 25(7): 877887. PMid:20503176.

Giunchetti RC, Mayrink W, Genaro O, Carneiro CM, Corrêa-Oliveira R, Martins-Filho OA, et al. Relationship between canine visceral leishmaniosis and the Leishmania (Leishmania) chagasi burden in dermal inflammatory foci. J Comp Pathol 2006; 135(2-3): 100-107. http://dx.doi.org/10.1016/j. jcpa.2006.06.005. PMid:16959259.

Gramiccia M. Recent advances in leishmaniosis in pet animals: Epidemiology, diagnostics and anti-vectorial prophylaxis. Vet Parasitol 2011; 181(1): 2330. http://dx.doi.org/10.1016/j.vetpar.2011.04.019. PMid:21570192.

Laurenti MD, Rossi CN, Matta VL, Tomokane TY, Corbett CE, Secundino NF, et al. Asymptomatic dogs are highly competent to transmit Leishmania (Leishmania) infantum chagasi to the natural vector. Vet Parasitol 2013; 196(3-4): 296-300. http://dx.doi.org/10.1016/j.vetpar.2013.03.017. PMid:23562649.

Menezes-Souza D, Guerra-Sá R, Carneiro CM, Vitoriano-Souza J, Giunchetti RC, Teixeira-Carvalho A, et al. Higher expression of CCL2, CCL4, CCL5, CCL21, and CXCL8 chemokines in the skin associated with parasite density in canine visceral leishmaniasis. PLoS Negl Trop Dis 2012; 6(4): e1566. http://dx.doi.org/10.1371/journal.pntd.0001566. PMid:22506080.

Ordeix L, Solano-Gallego L, Fondevila D, Ferrer L, Fondati A. Papular dermatitis due to Leishmania spp. infection in dogs with parasite-specific cellular immune responses. Vet Dermatol 2005; 16(3): 187-191. http:// dx.doi.org/10.1111/j.1365-3164.2005.00454.x. PMid:15960633.

Papadogiannakis EI, Koutinas AF, Saridomichelakis MN, Vlemmas J, Lekkas S, Karameris A, et al. Cellular immunophenotyping of exfoliative dermatitis in canine leishmaniosis (Leishmania infantum). Vet Immunol Immunopathol 2005; 104(3-4): 227-237. http://dx.doi.org/10.1016/j. vetimm.2004.12.001. PMid:15734543.

Queiroz NM, Assis J, Oliveira TM, Machado RZ, Nunes CM, StarkeBuzetti WA. Diagnóstico da leishmaniose visceral canina pelas técnicas de imunoistoquímica e PCR em tecidos cutâneos em associação com a RIFI e ELISA-teste. Rev Bras Parasitol Vet 2010; 19(1): 32-38. http:// dx.doi.org/10.4322/rbpv.01901006. PMid:20385057.

Queiroz NMGP, Silveira RCV, Noronha ACF Jr, Oliveira TMFS, Machado RZ, Starke-Buzetti WA. Detection of Leishmania (L.) chagasi in canine skin. Vet Parasitol 2011; 178(1-2): 1-8. http://dx.doi.org/10.1016/j. vetpar.2010.12.033. PMid:21295916.

Ramos RAN, Ramos CAN, Santos EMS, Araújo FR, Carvalho GA, Faustino MAG, et al. Quantification of Leishmania infantum DNA in the bone marrow, lymph node and spleen of dogs. Rev Bras Parasitol Vet 2013; 
22(3): 346-350. http://dx.doi.org/10.1590/S1984-29612013000300005. PMid:24142164

Reis AB, Martins-Filho AO, Teixeira-Carvalho A, Carvalho MG, Mayrink W, França-Silva JC, et al. Parasite density and impaired biochemical/ hematological status are associated with severe clinical aspects of canine visceral leishmaniasis. Res Vet Sci 2006; 81(1): 68-75. http://dx.doi. org/10.1016/j.rvsc.2005.09.011. PMid:16288789.

Reis LE, Coura-Vital W, Roatt BM, Bouillet LE, Ker HG, Brito RCF, et al. Molecular diagnosis of canine visceral leishmaniasis: a comparative study of three methods using skin and spleen from dogs with natural Leishmania infantum infection. Vet Parasitol 2013; 197(3-4): 498-503. http://dx.doi. org/10.1016/j.vetpar.2013.07.006. PMid:23953760.

Saridomichelakis MN, Koutinas AF, Olivry T, Dunston SM, Farmaki $\mathrm{R}$, Koutinas CK, et al. Regional parasite density in the skin of dogs with symptomatic canine leishmaniosis. Vet Dermatol 2007; 18(4): 227-233. http://dx.doi.org/10.1111/j.1365-3164.2007.00597.x. PMid:17610487.

Solano-Gallego L, Fernandez-Bellon P, Morell P, Fondevila D, Alberola J, Ramis A, et al. Histological and immunohistochemical study of clinically normal skin of Leishmania infantum-infected dogs. J Comp Pathol 2004;
130(1): 7-12. http://dx.doi.org/10.1016/S0021-9975(03)00063-X. PMid:14693119.

Tafuri WL, Santos RL, Arantes RM, Gonçalves R, de Melo MN, Michalick MS, et al. An alternative immunohistochemical method for detecting Leishmania amastigotes in paraffin-embedded canine tissues. J Immunol Methods 2004; 292(1-2): 17-23. http://dx.doi.org/10.1016/j. jim.2004.05.009. PMid:15350508.

Torres-Neto R, Rodrigues MMP, Amorim RL, Conceição LG, Luvizotto MCR, Franco SRVS. Padrôes histopatológicos das lesôes descamativas e ulcerativas da pele em cães com leishmaniose. Semina: Cienc Agrar 2008; 29(3): 667-676.

Travi BL, Tabares CJ, Cadena H, Ferro C, Osório Y. Canine Visceral Leishmaniasis in Colombia: relationship between clinical and parasitological status and infectivity for sand flies. Am J Trop Med Hyg 2001; 64(3-4): 119-124. PMid:11442205.

Veras PST, Santos WLC, Almeida TF, Rodrigues CAT. Primary immune response and parasite dissemination in Canine Visceral Leishmaniasis. Anim Biol J 2010; 1(4): 205-221. 